\title{
LOCAL POWER AND GLOBALIZATION: SOCIAL EMPOWERMENT AND THE PROTECTION OF NATURAL HERITAGE IN BRAZILIAN FEDERALISM
}

\section{PODER LOCAL E GLOBALIZAÇÃO: O EMPODERAMENTO SOCIAL E A PROTEÇÃO DO PATRIMÔNIO NATURAL NO FEDERALISMO BRASILEIRO}

\author{
Grace Ladeira Garbaccio ${ }^{1}$ \\ Jeferson Dytz Marin ${ }^{2}$ \\ Jamile Brunie Biehl ${ }^{3}$
}

\begin{abstract}
The Federal Constitution of 1988 of the Federative Republic of Brazil, in its provisions, provided the municipalities with autonomy to conduct local socioeconomic development and land use planning, aiming at the healthy quality of life of the population and sustainable development of the place. This article draws some lines on the importance of the use of municipal laws as tools of local environmental protection. Based on the research line Globalization, Environmental Law, Public Policies and
\end{abstract}

\footnotetext{
${ }^{1}$ Professora do Programa Stricto Sensu - Mestrado em Direito do IDP. Doutora e mestre em Direito pela Universidade de Limoges/ França - reconhecido pela Universidade Federal de Santa Catarina (UFSC). Professora do curso de pós-graduação lato sensu da ESPM, FIA e FMU. Professora convidada da Université Laval/Québec e professora visitante da Business School da Católica do Porto/UCP. Instituto IDP - Brasil. ORCID: https://orcid.org/0000-0002-0658-9472 Lattes: http://lattes.cnpq.br/4891035484304681 E-mail: glgarbaccio@hotmail.com

2 Doutor em Direito - UNISINOS-RS. Advogado. Coordenador do programa stricto sensu em Direito da UCS-RS. Professor do Programa de Mestrado e Doutorado em Direito da UCS-RS. Professor da pós-graduação de diversas instituições de Ensino Superior, dentre as quais, ESMAFE, UNOESC, UNISINOS e UNIFRA. Membro Honorário da ABDPC - Academia Brasileira de Direito Processual Civil. Membro do IEM - Instituto de Estudos Municipais, ministrando aulas em São Paulo, Rio Grande do Sul, Paraná, Santa Catarina e Bahia. Autor de diversos livros jurídicos, dentre os quais, Relativização da Coisa Julgada e inefetividade da jurisdição (Juruá, 2015), Crise da Jurisdição e Decisionismo em Alexy: Prisioneiros da Liberdade (Juruá, 2015), Liberdade de Orientação Sexual: gênero, identidade e democratização de afeto (Juruá, 2015), Jurisdição e Processo IV: coisa julgada (Juruá, 2013), Estado, Jurisdição e Meio Ambiente (EDUCS, 2012), ISS: tributação bancária e aspectos controversos (Juruá, 2009), Jurisdição e Processo: efetividade e realização da pretensão material (Juruá,2008/2012), Jurisdição e Processo II: reformas processuais, ordinarização e racionalismo (Juruá, 2009) e Jurisdição e Processo III: estudos em homenagem a Ovídio Baptista da Silva (Juruá, 2009). Universidade de Caxias do Sul - UCS, Rio Grande do Sul - Brasil. ORCID: https://orcid.org/0000-0002-7241-5243 Lattes: http://lattes.cnpq.br/0169455265201716 Email: glgarbaccio@hotmail.com

${ }^{3} 2019$ - atual Doutoranda em Direito. Universidade de Caxias do Sul, UCS, Caxias Do Sul, Brasil. 2016 - 2018 Mestrado em Direito Ambiental. Universidade de Caxias do Sul, UCS, Caxias Do Sul, Brasil. 2014 - 2015 Especialização em Direito Ambiental. Verbo Jurídico, VERBO JURÍDICO, Brasil. 2013 - 2014 Especialização em Direito Constitucional. Anhanguera Uniderp LFG, LFG, Brasil. 2008 - 2012 Graduação em Direito. Universidade do Vale do Rio dos Sinos, UNISINOS, São Leopoldo, Brasil. Universidade de Caxias do Sul, UCS, Caxias Do Sul, Brasil. ORCID: https://orcid.org/0000-0003-1704-1813 Lattes: http://lattes.cnpq.br/8760709032609892 E-mail: glgarbaccio@hotmail.com
} 
Socioeconomic Development, the objective is to discuss and enable a relationship between the legitimacy of local power and popular participation when using environmental impact mitigation tools to prior planning within the Municipalities and the effective environmental preservation through the use of the current environmental legislation. Thus, through the analysis of land use and occupation of an intentional area of the Municipality of Montenegro - Rio Grande do Sul, it was confirmed the premise that in the region, because it has a wide standardization with the scope of protecting the areas of environmental restriction and previous studies on land use and management that allowed for public participation in decision-making processes, the municipality controls significantly the advances of urban expansion on the areas of environmental restriction, verifying that through participatory democracy it is possible for the local power to decide on the matters to their local peculiarities, which generates the empowerment of the common citizen and fosters the feeling of belonging and protection to the place that is inserted.

Keywords: Environment; Municipal Planning; Local Power

\section{RESUMO}

A Constituição Federal de 1988 da República Federativa do Brasil, em seus dispositivos, dotou de autonomia os Municípios para que estes conduzissem práticas locais de planejamento de desenvolvimento socioeconômico e ordenação de uso do solo, visando a sadia qualidade de vida da população e o desenvolvimento sustentável do local. O presente artigo traça algumas linhas sobre a importância da utilização de leis municipais como ferramentas de proteção ambiental local. Partindose da linha de pesquisa globalização, Direito Ambiental, Políticas Públicas e Desenvolvimento Socioeconômico, o objetivo é discutir e possibilitar que se estabeleça uma relação entre a legitimação do poder local e da participação popular quando da utilização dos instrumentos de mitigação dos impactos ambiental ao planejamento prévio dentro dos Municípios e a efetiva preservação ambiental através da utilização da legislação ambiental vigente. Desse modo, através da análise de uso e ocupação do solo de uma área intencional do Município de Montenegro - Rio Grande do Sul foi confirmado a premissa de que na região, por possuir uma vasta normatização com o escopo de tutelar as áreas de restrição ambiental e estudos prévios de uso e ordenação do solo que possibilitaram a participação Pública nos processos decisórios, o Município controla significativamente os avanços de expansão urbana sobre as áreas de restrição ambiental, verificando-se que por meio da democracia participativa é possível ao poder local decidir sobre as matérias afeitas as suas peculiaridades locais, 
que gera o empoderamento do cidadão comum e acalenta o sentimento de pertencimento e proteção ao local que está inserido.

Palavras-chaves: Meio Ambiente; Planejamento Municipal; Poder Local.

\section{INTRODUCTION}

Human occupation within cities is a natural process that spreads with the very conception of human evolution. The frailty of men, the duty to protect the family and provide support for all those who depended on them, made the occupation of natural spaces an interventionist model due to the anthropological needs of man, in order to meet the premises of coexistence and human safety. Therefore, the territories that nowadays concern cities have as their essence "the common vision of a better and more meaningful life, while at the same time being aesthetically attractive" ${ }^{4}$.

In Brazil, a decentralized state model is adopted, divided in regions, to which, through processes articulated by the central power, have become a federation, where the federative pact is the result of a univocal decision not being effectively constructed by its territorial bases. The federative organization foreseen and guaranteed in the constitutions of the respective States can be understood as the political system in which territorial and political groupings come together to originate a larger organization. In the federal model, the member states that are part of the Union keep their political, administrative and financial autonomy, failing to exercise certain prerogatives in favor of a new political figure supra sized in relation to the local units, highlighting, in this system, the sovereignty as the most relevant of prerogatives ${ }^{5}$.

In this sense, in a federalist base state, the states that integrate it maintain considerable political, administrative and financial autonomy, disentangling itself from its sovereignty. The Federal Constitution of 1988 is responsible for ensuring local autonomy as well as organizing the political cooperation form of the power division.

The essence of the federative principle lies in the separation of jurisdictions and distribution of tax revenues, which is in line with the autonomy of states and municipalities. This characteristic impacts the autonomy of the Entities closest to the citizen, that is, the Municipalities. The autonomy granted to the municipal entity contributes to its fundamental role as local-author, while it is

\footnotetext{
4 LeWIS Mumford, A CidAde nA HISTÓRIA 14 (Neil da Silva trans, 4 ed., M. Fontes 1998).

5 Hermany \& Giacobbo, DescentralizaÇão e Municipalismo no Brasil 46 (2017).
} 
responsible and authorized on its own political-administrative logic in which they lead to a decentralization of matters of local interest, notably with regard to the creation of public policies themselves ${ }^{6}$.

Through participatory democracy, it is possible for the local power to decide on the local matters, which generates the empowerment of the ordinary citizen and fosters the feeling of belonging and protection to the place that it is inserted. Such autonomy is based on the capacity of the municipal entity to self-govern, self-administer and self-organize, mainly by the possibility of creating its own normatively - embodied in organic law - in the elaboration of its own master plan, in the capacity to produce pertinent norms to matters of local interest and additional legislative competence with regard to federal and state legislation.

\section{DECENTRALIZATION AND LOCAL POWER IN BRAZIL: A PERSPECTIVE BASED ON SHARED ENVIRONMENTAL MANAGEMENT.}

The Federal Constitution endowed the Municipalities in a complementary manner in accordance with section 30, items I and II, to legislate on matters of local interest and to elaborate their own organic law, with a view to attending to local demands precisely. Considering that it is in the Municipalities that the urban activity is exercised in a more dynamic and objective way, it is necessary for the Municipal Public Power to use the greater number of existing local legal instruments with the purpose of ordering and organizing their territory, focused on creating suitable zones with the activities developed, guaranteeing the urban mobility and the infrastructure of the whole place. In these terms, many measures are apt and established, such as control and land use through environmental Zoning, prior planning through Municipal Public Management, Master Plan, Popular Participation, Cities Statute and Environmental Management through Public Policies ${ }^{7}$. Still, regarding the urban management of the territories, the Constitutional Charter in its section 24, item I, regarding the matter of urban law that the competence to legislate on the subject competes between Union, States and Federal District.

In Act 10,257, section 2, that is, in the Cities Statute, the general urban planning guidelines of these territories are listed, where they expressly state the urban planning principles to be

\footnotetext{
${ }^{6}$ Hermany \& Giacobbo, Descentralização e Municipalismo no Brasil 50 (2017).

7 Marli Marlene da Costa \& Suzéte da Silva ReIS. Espaço local: O EsPaço do CidAdão e da CidadANia 262 (Editora IPR 2010).
} 
implemented in cities and in Brazilian urban properties, representing a true instrument of construction of law to sustainable cities. Its commands refer to an intergenerational equity, with the purpose of guaranteeing urban land, housing, environmental sanitation, urban infrastructure, transportation and public services, as well as work and leisure for all who inhabit Brazilian Municipalities ${ }^{8}$.

The municipal autonomy provided by the Brazilian federal state model is based on the principle of decentralization and subsidiarity, the latter implicit in the Brazilian constitutional order. This autonomy surpasses those foreseen in the Brazilian constitutional order and is obtained through the promulgation of the Federal Constitution of 1988, being the same form of an autonomy corresponding to the means of structuring in articulated form with the local society its own public policies, which is perfectly in line with the premises of the Magna Carta.

Through the principle of subsidiarity, it is possible to articulate a local power that allows the concretion of an institutional space of competences of a new and qualified relationship between state institutions and society. Within municipal bodies, subsidiarity, as part of the model of national federalism, presupposes that any decision that can be taken by the closest authorities - whether institutional or not - must take place in this way and must be delegated only in cases of greater efficiency or reasons of economic order - which for the most part occurs, especially from a socioenvironmental perspective.

Regarding local sustainability, despite the premise that the environment is considered to be a worldwide community and with no territorial limits, the scope of all illegal practices has no borders, which requires a diffuse cooperation regarding the control of natural exhaustion. Environmental protection must begin within neighborhoods, communities, municipalities and gradually be extended to a planetary dimension. Local measures must always be in line with environmental principles and global parameters, considering the existence of a conception of citizenship in a global dimension and recognizing the importance of Environmental Education in the most diverse levels of knowledge, focusing on forming active and conscious citizens within their communities.

Today, citizenship presents another dimension. The question of its exercise transcends internationalization and invades globalization. This is due to the fact that production has destructive effects throughout the planet, no longer circumscribing the geopolitical parameters of internationalism, but advancing to the question of the very survival of the planet and the human species. This leads to the human being's need to conceptualize itself differently. No longer a citizen who dominates nature to create his world, but a being of nature who creates his world by living together with it. This planetary citizen has in the environmental question one of the most serious political and human problems of

\footnotetext{
8 Cidades Sustentáveis, Subsídios à Elaboração da Agenda 21 Brasileira p49 (Brasília, Ministério do Meio Ambiente 2000).
} 
contemporaneity. The human being has reached the point of being able to destroy itself as a species ${ }^{9}$.

The interaction between civil society and the defense of the environment is more intense and evident within the Municipalities, which better represents the physical and cultural characteristics of each territory. In order to do so, the Municipal Planning with the use of norms of urbanistic law as a means of control the environmental degradation in the local spaces is an indispensable measure of socio-environmental management, territories where active citizens are inserted and exercising their social representativity more immediately within the communities.

The importance of the use of protective measures at the municipal level is evident in the fact that the management of the existing instruments must be consistent with the factual, cultural and social reality, which legitimizes the impact on their legal system, otherwise they will become innocuous. In this sense that the adoption of Municipal Public Policies becomes paramount, they are endowed with effectiveness because they are close to the local realities of each community, which shows the deficiencies and potential of each municipality to be solved primarily ${ }^{10}$. In the materialization of actions of local interest, the importance of Environmental Management and Municipal Public Policies is evidenced, which have the function of seeking the internalization of externalities through legal norms and strategic planning. In this sense, the Master Plan is the instrument that guides the bases of action of the Public Power, since it seeks to organize the activities developed in society, maximizing their benefits and avoiding that they interfere with each other through an efficient Municipal Public Administration.

As a way of ensuring a sustainable environment that does not compromise the economic and social development of Municipalities, Environmental Management and the use of Public Policies are presented as a planning tool for these territories as well as a determinant tool for the development of a certain artificial/natural space, they do not nullify the possibility of urban and industrial expansion of the Municipalities, and only neutralize their effects. The Municipalities depend on the protection of the natural patrimony aiming to guarantee the sustainability and the environment of the sustainability by the use of its own space, to which Jeferson Dytz Marin and Carlos Alberto Lunelli understand is due to the principle of the unavailability of the environmental good that the principle of obligatory state intervention in the defense of the environment, as provided for in section 225 of the Federal

\footnotetext{
${ }^{9}$ Roberto ARMANDo RAMOS de AgUiar, DiREITO do MEIO AMBIENTE E PARTICIPAÇão POPULAR 46 (Edições Ibama 1998).

${ }^{10}$ KonRad HeSSE, A ForÇa Normativa da Constitulção 24 (Gilmar Ferreira Mendes trans., Fabris 1991).
} 
Constitution, has been established, which establishes that the environment must be protected by the State acting jointly by federated entities ${ }^{11}$ in order to guarantee a healthy quality of life.

The right to an ecologically balanced environment, given its importance and unavailability, is

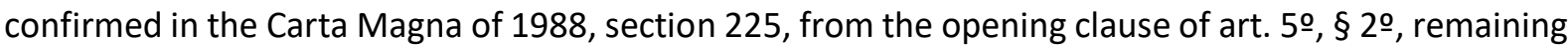
elevated to the status of fundamental right of the individual and of the collectivity ${ }^{12}$. Likewise, urban law contains the status of a fundamental right, since it is closely linked to the well-being of citizens, fulfilling the objective of a reorganization of urban space, constituting the right to a sustainable city one of the general guidelines set forth in subsection I of section 2 of the City Statute, which aims at the full development of the social functions of the city and urban property, and is conceptualized as "the right to urban land, housing, environmental sanitation, urban infrastructure, transportation and public services, work and leisure, for present and future generations "13.

By using the Public Power and Municipal Management of the norms of urban law to correct problems of distortions of growth, urban expansion becomes a technical and safe procedure, hence the normative provisions establish legally the parameters and guidelines to be followed in order to organize the urban spaces, mitigating the negative effects of the present actions aiming at achieving sustainable intergenerational development. The correction of these practices must begin in the cities themselves, through urban planning of social inclusion ${ }^{14}$. According to Rech, "the urban norm does not impose a simple present behavior that restricts the standard itself, but which ensures the future. It is a branch of law that is in permanent construction and is based on all other sciences [... $]^{\prime 15}$.

Each Municipal reality rises different plans of action to be taken to remedy the inequalities and problems that exist in it, very peculiar and cultural. Therefore, it is at this point that acting worldwide is not efficient enough if local reality is not considered with its most characteristic requirements, although the current character of globalization is recognized. According to the considerations of Costa and Kings, it can be pointed out:

The local space presents itself as ideal, since the proximity of the citizens with the decision centers is greater. Moreover, there is a greater commitment of

\footnotetext{
${ }^{11}$ Jeferson Dytz Marin \& Carlos Alberto Lunelli, Processo Ambiental, Efetividade e as Tutelas de Urgência, Veredas do Direito, Vol. 7, no13-14 (Aug. 2011).

12 KonRad HesSe, Elementos de diReito constitucional dA República Federal dA Alemanha 239 (Luis Afonso Heck trans., Fabris 1998).

13 10.257 Act 2001, section 2 (Brazil).

14 Adir Ubaldo Rech \& Adivandro Rech, Direito Urbanístico: Fundamentos Para Construção de um Plano Diretor Sustentável na Área Urbana e RuRal 10 (Educs 2010).

15 Adir Ubaldo Rech \& Adivandro Rech, Direito Urbanístico: Fundamentos Para Construção de um Plano Diretor Sustentável na Área Urbana e Rural 38 (Educs 2010).
} 
citizens, because it is in the local space that he lives, works, has fun, lives with others, in short, it is where he experiences his rights and his duties as a citizen ${ }^{16}$.

The principle of subsidiarity, based on the logic of a primary action, should be carried out in the smaller communities, starting from the individuals to only from a subsidiary perspective invoke the performance of the state public power, which generates elements of empowerment and sovereignty of the individual. dialogue and decisions of the citizens encourage their political participation and the establishment of pluralist dialogues ${ }^{17}$.

Such an appreciation of local citizenship strengthens the role of smaller communities and citizens and ensures a delimited locus for state action, since it only works if the community cannot, by its own measures, deliberate and decide on public affairs - which complies with the principles of public interest, encourages the involvement of citizens at different levels and reinforces the idea of participatory democracy.

In this process, there is a recognition of values and clarification of concepts, aiming the development of skills and modifying the attitudes of the population towards the environment, to understand and appreciate the interrelationships between human beings, their cultures, their biophysical means and the cities.

Therefore, the Environmental Education to be instituted through Public Policies by the Public Power is essential. There is no way the State can take responsibility for the defense of the environment if the national community is not aware of the unavailability of environmental patrimony. Thus, it is of the utmost importance that it is applied at all levels of learning so that the entire population is aware that the natural resources are exhaustible, and the lack of urban and social planning generates their scarcity and impedes the quality of life of the residents, unbalancing the natural cycles of which man belongs. This education, consequently, should be directed towards the construction of an active citizenship by awakening in the citizens their sense of belonging and co-responsibility which, through collective and organized action, seeks to understand and overcome the structural and conjunctural causes of environmental problems within urban spaces ${ }^{18}$.

Thus, in the process of sustainable development focusing on minimizing the socioeconomic impacts of different regions and systematic and gradual awareness of the population, planning

\footnotetext{
${ }^{16}$ Marli Marlene da Costa \& SUzÉte dA Silva ReIs. Espaço Local: O Espaço do CidadÃo e da CidAdania 104 (Editora IPR 2010).

${ }^{17}$ Hermany \& Giacobbo, Descentralização e Municipalismo no Brasil 60 (2017).

${ }_{18}$ Marcos Sorrentino et al, Educação Ambiental Como Política Pública, EDUCAÇÃo E PESQUISA, Vol. 31, №2, 2005, at 285.
} 
becomes essential - which is done through the application of Municipal law. The lack of planning for the implementation of Public Policies causes the lack of effectiveness of the Master Plan at the Municipal level. In reality, only large enterprises and large centers, occupied by the more elitist inhabitants of the Municipalities, are planned, ignoring the social and environmental aspects that are the foundation of sustainable urban law and the social aspects of each community. The consequences of an unplanned urbanization are numerous and well-known, since through their lack the most diverse problems of urban and rural occupation arise, leading to chaos in the Municipalities resulting from the disordered occupation ${ }^{19}$, generating the production of misery, degradation of the environment, and creation of large suburbs without basic sanitation and infrastructure. In this thought, Daniella Dias affirms:

It is observed that in relation to the ineffectiveness of the protection of Permanent Preservation Areas, the public policies that are carried out randomly and the Master Plan, established primordial to draw the guidelines and rules for the implementation of urban development and expansion policies, still does not have the necessary relevance in Brazilian municipalities. [...] municipal administrators have not yet become aware of the importance of the existence and effectiveness of the Master Plan for the fulfillment of the social functions of the city and of the property ${ }^{20}$.

The general urban policy guidelines established in the City Statute as general norms of urban law are in particular for Municipalities, the norms that guide and imply the application of the urban policy instruments regulated in the law. The practice of urban planning rather than establishing models for the functioning of municipalities has a function of correcting the imbalances of the orders caused by urbanization, being an important instrument of social transformation, using accurate data and information with local diagnoses.

Municipalities and cities represent the places where informally pointing out there are jobs, goods, the municipal government headquarters, public squares and other public services (schools, hospitals, notary offices), cultural options, restaurants and major spaces of leisure ${ }^{21}$. As stated by Prestes, the right to the city is a concept under construction, whose constitutional dimension stems from the Democratic Socio-environmental State of Law. According to the author, "the fundamental right to the city derives from the symbiosis of the ecologically balanced right to the environment ${ }^{22}$,

\footnotetext{
${ }^{19}$ Adir Ubaldo Rech \& Adivandro ReCh, Direito Urbanístico 81 (EDUCS 2015).

20 Daniella S. Dias, A Efetividade do Direito Urbanístico Após Vinte Anos da Promulgação da Constituição Brasileira, REVISTA DE INFORMAÇÃO LEGISLATIVA Vol. 47, no186, Apr./Jun., 2010, at 83.

${ }^{21}$ ELIDA SÉGUIN, ESTATUTO DA CIDADE 3 (Forense 2002).

22 BRASIL CONST. Art. 225.
} 
from the right to urban policy ${ }^{23}$ to the right to democratic management and housing ${ }^{24 "}$. These guarantees derive from the fundamental rights, being the city the space for this realization and experience ${ }^{25}$.

\section{THE MUNICIPAL LEGAL INSTRUMENTS OF ENVIRONMENTAL PROTECTION IN BRAZILIAN FEDERALISM.}

The importance of objective and precise planning regarding the territories within the Municipalities has already been highlighted. The legal provisions pertinent to the Municipal planning privilege the federative pact in defining the competences of the Union, the States and the Municipalities in the normative and executive field of Urban Public Policies, as well as in determining the fundamental principles that consolidate the urban policy with the purpose of assuring the right to the city ${ }^{26}$.

The Ministry of the Environment provides that the planning of the Municipalities is a constitutionally assured guarantee of municipal management, to be achieved through the application of environmental planning instruments, tools which, according to all of the above, are related to the quality of life of the population and of the environment that are included in the urbanization process.

The Master Plan is the main instrument of urban policy planning instituted by the Federal Constitution and enumerated in the Statute of the cities in its sections 39 to 42 . Its relevance rests mainly on the fact that it has a more systematized and efficient mechanism than the other instruments of urban policy (installment, compulsory building, progressive property tax (IPTU), expropriation, among others), as well as being subject to numerous validity requirements and guiding directives ${ }^{27}$, enabling and requiring the participation of all the population and specialists of the most diverse subjects in its process of implementation and elaboration of plans and urbanistic projects. The Master Plan still stands out because it allows to organize the growth, the operation and the planning of the territories, always with the observance of the environmental protection in all their acts.

\footnotetext{
${ }^{23}$ BRASIL CONST. Art. 182 and 183.

${ }^{24}$ BRASIL CONST. Art. 6.

${ }^{25}$ Vanêsca Buzelato Prestes. Dimensão constitucional do direito à cidade e formas de densificação no Brasil. [dissertation]. Porto Alegre: Pontifícia Universidade Católica do Rio Grande do Sul - PUCRS; 2008.

${ }^{26}$ ZÉLIA LEOCÁDIA DA TRINDADE JARDIM, REgULAMENTAÇÃo dA PolítICA URBANA E GARANTIA Do DIREITO À CIDADE 98 (2007)

27 José Afonso Silva. Direito Ambiental Brasileiro. Direito Urbanístico Brasileiro 56 (3 ed., Malheiros 1997).
} 
In this scenario, this legislative instrument allows the citizen to act actively in the environmental, social and cultural protection of the Municipalities, considering that historically the master plans have always been treated by technicians and specialists. This participation of the population is not restricted to the process of elaboration of the Master Plan Law, but it covers the entire implementation process, for example, in the use of urban policy tools such as: neighborhood impact study, environmental impact study, budget planning, among others.

According to Janaína Rigo Santin and Ricardo Quinto Mattia apud Edésio Fernandes:

The Federal Constitution granted the Municipality jurisdiction to act in the control of urbanization, and the Statute of the Cities regulated the constitutional instruments foreseen for this intervention as well as created a broader range of instruments. Such instruments can and should be used by the Municipalities so that the processes of use, development and occupation of urban land are satisfactory and so that the Brazilian cities can offer better living conditions for the population, offering land regularization to the illegal cities and inhibiting the use of property for speculative purposes, which causes social exclusion and poor spatial ordering ${ }^{28}$.

Thus, the Statute of Cities validated the Master Plan as a determinant instrument aimed at the quality of life of citizens, by pointing it as a tool to be used for the construction of a new model of Municipality. The Master Plan, approved by municipal law, "is the basic municipal law for the policy of development and urban expansion"29. Therefore, it approximates urban guidelines to local realities, which should be periodically reviewed with the scope of guaranteeing their effectiveness in municipal management, taking into account cultural needs and mutations over time.

Due to these considerations, it began to be absorbed and considered the main instrument of Urban Policy in the Federal Constitution of 1988. The aforementioned complementary legislation became necessary to the urban policy before its association with reality. Article 182 of the Constitution states that the urban development policy must be implemented by the Municipal Government, in accordance with the guidelines established by law. In the words of Rech and Rech:

Thus, it is the responsibility of municipalities to draw up a policy of urban development, which is a synonym of planning. Development policy, once drafted and transformed into a law, is considered to be a development plan ${ }^{30}$.

\footnotetext{
${ }^{28}$ Janaína Rigo Santin \& Ricardo Quinto Mattia, Direito Urbanístico e Estatutos das Cidades, REVISTA DE DIREITO IMOBILIÁRIO Vol. 30, nㅇ6, 2007, at 49.

${ }^{29} 10.257$ Act 2001, section 40 (Brazil).

30 Adir Ubaldo Rech \& Adivandro Rech, Zoneamento Ambiental como Plataforma de Planejamento da SUSTENTABILIDADE: INSTRUMENTOS DE UMA GESTÃo AMBIENTAL, URBANÍSTICA E AGRÁRIA PARA O DESENVOLVIMENTO SUSTENTÁVEL 90 (Educs 2012).
} 
Its legal nature is an instrument of Municipal Planning and its implementation is mandatory in Brazilian Municipalities that contain more than twenty thousand inhabitants, members of metropolitan regions and urban agglomerations, before those, which the Municipal Government intends to use the instruments of installment or building compulsory property tax on urban land and property taxes progressive in time or expropriation with payment through debt securities, members of areas of special tourist interest, as well as in areas listed as influencing ventures or activities with significant environmental impact at the regional or national levels.

In this sense, for the implementation of the Master Plan in a given municipality there are a set of criteria based on several factors to be observed, in which the public manager is not the sole responsible for its observation as well as civil society, which must actively participate in the acts of Municipal Planning, making this tool extremely effective in the socio-environmental evolution of citizens and the environment.

The current vision of the Master Plan differs greatly from its earlier conception. From a mere administrative document aimed at solving all local problems, disregarding daily social practices, the Master Plan assumes the function of interfering in the local development process, based on the integrative understanding of political, economic and financial factors, cultural, environmental, institutional, social and territorial that condition the situation found in the Municipality ${ }^{31}$.

In the planning process, natural resources are considered, even if it is a different instrument from environmental zoning. In the implementation phase, a diagnosis is initially extracted, on which in this act, a vast survey of all the data, information and statistics that make the visualization of the territory safe and accurate, according to the local reality, is carried out. For such, a study is carried out by a multidisciplinary team, taking into account the contributions that each science of knowledge can give to the process. According to Motta, these data refer not only to population data, but also those specific to the physical, biotic, ecosystem, anthropic, and other environments ${ }^{32}$. That is, all the local aspects of the territory.

The guidelines of the Plan must always be formulated in order to ensure the right conditions of life for the inhabitants and, for this to be achieved, it should aim at the protection of natural resources. In its execution, from the survey of the existing conditions to the formulation of the guidelines and elaboration of the basic legislation, the Plan should aim at the conservation of the urban environment, thus understood the use of available resources without

\footnotetext{
31 Isabel Cristina Eiras de Oliveira, Estatuto da Cidade: PARA Compreender... 18 (IBAM\DUMA 2001).

32 Suetônio Motta, URBANIZAÇÃo e MeIo AMBiente 275 (Abes 2003).
} 
compromising the quality of the same, ensuring their use by current and future generations ${ }^{33}$.

In order to ensure the effectiveness of the use of such surveys, section 40 of the Statute of Cities lay out the need for the formulation process of the Master Plan and for monitoring its implementation to be feasible with social participation, making use of, in the most varied stages of the process, public hearings and debates with citizen participation.

Therefore, in Brazilian federalism, all techniques designed to make a diagnosis and prognosis of reality, as well as defining basic principles and guidelines, should be translated into rules of law, in the Master Plan, since nothing happens in the public administration that is not foreseen in law. The law is the main instrument of public management planning, and as such should be addressed. The Master Plan meets all these expectations, as provided by law and in the right measure to comply with the norms and general guidelines of urban planning ${ }^{34}$.

Such a Plan is a fundamental procedure of urban planning and healthy expansion of the Municipalities, since it makes possible the organization of urban growth, in the same sense, environmental Zoning plays an indispensable role insofar as it is the legal instrument of land use and occupation , to which it consists in the distribution of the municipal territory aiming at the destination of the land and its use. It stipulates the qualification of the soil in terms of urban planning, urban expansion, urban development and rural development, and also divides the territory of the Municipality into zones of use, regarding its purpose and areas of use ${ }^{35}$.

In the distribution of the city and of the urbanizable areas according to its main destination of use and occupation of the ground, observing that it usually establishes the residential, commercial, industrial and institutional areas; delimits the places of specific use; construction and permissible uses; orders circulation, transit and traffic in the urban perimeter, it disciplines collective or individual activities that in any way affect city life ${ }^{36}$.

Ioberto Tatsch Banunas points out that Celso Antônio Pacheco Fiorillo and Marcelo Abelha Rodrigues understand by zoning "a non-jurisdictional measure, derived from police power, with two main foundations: municipal urban land allocation and the designation of its use ${ }^{37}$. As Paulo de Bessa Antunes teaches: "it is a strong state intervention in the economic domain, organizing the spaceproduction relationship, allocating resources, interdicting areas, allocating others to these and not to

\footnotetext{
33 Suetônio Motta, Urbanização e Meio Ambiente 275 (Abes 2003).

${ }^{34}$ Adir UBALDo ReCH \& AdIVANDRo ReCH, DiReITo URBANístico 82 (EDUCS 2015).

35 José Afonso Silva, Direito Ambiental Constitucional 67 (4 ed., Malheiros 2002).

${ }^{36}$ Hely Lopes MeIRELles, Direito Municipal BRASILEIRO 341 (13 ed., Malheiros 2003).

37 IOBERTO TATSCH (, PODER DE POLÍCIA AMBIENTAL E O MUNICÍPIO: GUIA JURÍDICO DO GESTOR MUNICIPAL AMBIENTAL ORIENTADOR LEGAL DO CIDADÃO AMBIENTAL 23 (Saluna 2003).
} 
those activities, encouraging and repressing behaviors." ${ }^{38}$. In this way, it represents a means of guaranteeing that prior planning and coordination of the areas within the Municipalities occur, without being determined areas affected by certain prevailing market niches, degrading the environment, representing an indispensable instrument of organization and construction of sustainable Municipalities.

The environmental zoning, for José Afonso da Silva, is considered as one of the main instruments of municipal urban planning, configuring a Special Urban Plan, constituting "an urbanistic procedure, whose objective is to regulate the use of property, soil and of buildings in homogeneous areas in the interest of the well-being of the population "39. Conceived as an integrated planning tool, it clearly represents a possible solution for the rational use of resources, ensuring the maintenance of biodiversity, natural processes and ecosystem services. Through this territorial planning, it is possible to contain the advance of agricultural frontiers, intense processes of urbanization and industrialization, control of environmental degradation, based on technical criteria through previous studies.

The figure of environmental zoning extends the concept, because it will no longer be only an urban zoning, as an instrument that advocates a more harmonious structure for cities, given that it is not limited to their environment, but it does not change their essence or their nature. The emphasis is on the protection of areas of significant environmental interest, but still remains zoning of land use and occupation, always in the interest and well-being and the achievement of the quality of life of the population ${ }^{40}$.

Although the Federal Constitution does not contain a proper concept of zoning, it can be searched through Act 6.939/1981, section 9, item II, which defines environmental zoning as "an instrument of national environmental policy. ", As well as through section 225 of the Federal Constitution, which has standards whose content is to indicate the adoption of certain environmental zoning standards, as in paragraph III of $\S 1^{\circ}$ and $\S 4^{\circ}$ of the same section as examples of zoning.

This tool is closely linked to the idea of urbanism, since it was with the conception of defining urban spaces for certain purposes ${ }^{41}$, focused on planning modern industrial cities, that this instrument was opened as a means of guaranteeing the need for spatial organization ${ }^{42}$. The planning of the Municipalities in specific zones generates a harmonization in the regional growth aiming to guarantee the sustainable development and urban expansion of the Municipalities.

\footnotetext{
38 Paulo de Bessa Antunes, DiReito Ambiental 125 (16 ed., Atlas 2014).

39 José Afonso Silva, Direito URbanístico Brasileiro 291 (Revista dos Tribunais 1981).

40 José Afonso Silva, Direito Ambiental Brasileiro 193 (4 ed., Malheiro 2006).

41 Paulo de Bessa Antunes, DiReito Ambiental 126 (16 ed., Atlas 2014).

42 Gaston BARDET, O URBANISMO 18 (Papirus 1990).
} 
In this process, legal criteria and regulations are established so that certain shares of land, water courses, or even certain areas may or may not be used considering their unavailability, according to criteria pre-established by previous studies.

It is an instrument to rationalize the occupation of the territory, subsidizing the elaboration and regional plans directed to the sustainable development and to provide a technical base for the definition of the territorial ordering. It is the sectorization of the studied area in homogeneous spaces or problematic zones in relation to the potential of ecological offers, limitations and environmental and socioeconomic problems ${ }^{43}$.

The pre-established criteria, once signed, are binding and mandatory, both for individuals and for the Public Administration, representing an administrative limitation on the right to property and on the land ${ }^{44}$. These limitations are highly important in the control of urban growth, environmental degradation, and socio-environmental development, which imposes limits on the entrepreneur and the ungoverned urban expansion.

The zoning can be understood as an urbanistic procedure destined to fix the appropriate uses for several areas of the municipal soil. Or: intended to fix the various areas for the exercise of elementary urban functions. [...] therefore, it constitutes an urban planning procedure whose purpose is to regulate the use of land and buildings in homogeneous areas, in the interests of the well-being of the population ${ }^{45}$.

It is in the Municipal Director Plans that there are provisions on the planning of Municipalities and on the creation of zones with different uses, zones with different forms of occupation and zones of total protection and restriction of use, in the environmental aspect, through data obtained by an Environmental Zoning.

It is noted from the analysis of these instruments that in fact are the basic human needs of the human beings, whoever they are: food, housing, transportation, education, leisure and basic sanitation, that determine the structure of the municipalities and the quality of the biotic environment in which they live. The city's statute should be based on the full development of Municipal Planning, as well as Public Policies should be widely used to follow the local characteristics of each territory with

\footnotetext{
${ }^{43}$ Presidência da República. Secretaria de Assuntos Estratégicos. Programa de Zoneamento Ecológico-Econômico da Amazônia legal, p.8, (Brasília, DF: SAE/PR/CCZEE, 1991).

44 PAulo de Bessa ANTUnes, DiReito Ambiental 125 (16 ed., Atlas 2014).

45 José Afonso Silva, Direito Ambiental Brasileiro 241 (4. ed., Malheiro 2006).
} 
flexibility and coherence, adapting to the already existing and to the already constructed, as well as the different realities of the territories, letting the negative aspects of globalization absorb the peculiarities of each place ${ }^{46}$.

Territory is not only the result of the superposition of a set of natural systems and a set of systems of things created by man. When one speaks of territory one must, therefore, immediately understand that one is talking about used territory, used by a given population, with its most peculiar and intimate characteristics. ${ }^{47}$. The territory is the ground and the population, that is, an identity, the fact, the culture and the citizens' feeling of belonging to what belongs to them. Territory is the basis of work, of residence, of material and spiritual exchanges, and of life over which it influences.

In this context, the municipality, which has autonomy and responsibility for the management of local affairs, is responsible, together with the municipal managers, to draw up action plans to combat irregular expansion and environmental degradation. Furthermore, it is its responsibility to carry out the urban development policy, enforcing the legislation and directives that order the full development of the social functions of the city, guaranteeing the well-being of its inhabitants, having as its north the sustainable development and conservation of all the natural and cultural riches of each place.

\section{A LOOK FROM THE CASE STUDY: THE PROTECTION OF THE ENVIRONMENTAL RESTRICTION AREAS BY THE USE OF THE ENVIRONMENTAL ZONING AND THE MASTER PLAN IN THE MONTENEGRO MUNICIPALITY/RS - COMPLEMENTARY ACT 5.883/14}

In view of all the considerations mentioned before, the protection of the areas of social interest and environmental restriction within the Municipalities are of extreme importance to guarantee the sustainable development of the regions. In many places prone to urban expansion, there are regions of preserved natural vegetation and springs, which are systematically degraded with the occurrence of irregular subdivisions and urban waste deposits, despite the fact that they are environmental protection zones in the urbanization plan of Municipalities zoning.

\footnotetext{
46 Cidades Sustentáveis, Subsídios à Elaboração da Agenda 21 Brasileira p68 (Brasília, Ministério do Meio Ambiente 2000).

${ }^{47}$ Milton Santos, Por Uma nova Globalização: Do Pensamento Único A ConsciênCia Universal 96 (22 ed., Record 2012).
} 
The use and anthropic occupation of the zones of environmental restriction in the Municipalities generate problems often irreversible to the environment, that cannot restore the ecosystems present in the areas of environmental interest to the point of returning to the status to the quo of ecological preservation and maintenance. For this purpose, legal instruments are used as practical tools to control land use and occupation, in order to protect and organize the socioenvironmental and economic growth within the Municipalities.

Regarding those who have this purpose, priority is given to the Master Plan and Environmental Zoning, which have the scope of ensuring a specific protection to the Municipal Ecological Heritage of each municipality.

In the case of Montenegro, in addition to the Municipality owning the Master Plan, there is the 5.883 complementary Act 2014 which provides for the zoning, use and occupation of land in the Municipality of Montenegro. This law divides the municipality into nine specific areas intended for purposes consistent with the territory stipulated for its purposes. Following this legislation, the Municipality still has a zoning map from which the limits imposed by such laws are fragmented, accurately referencing the boundaries of each zone. 


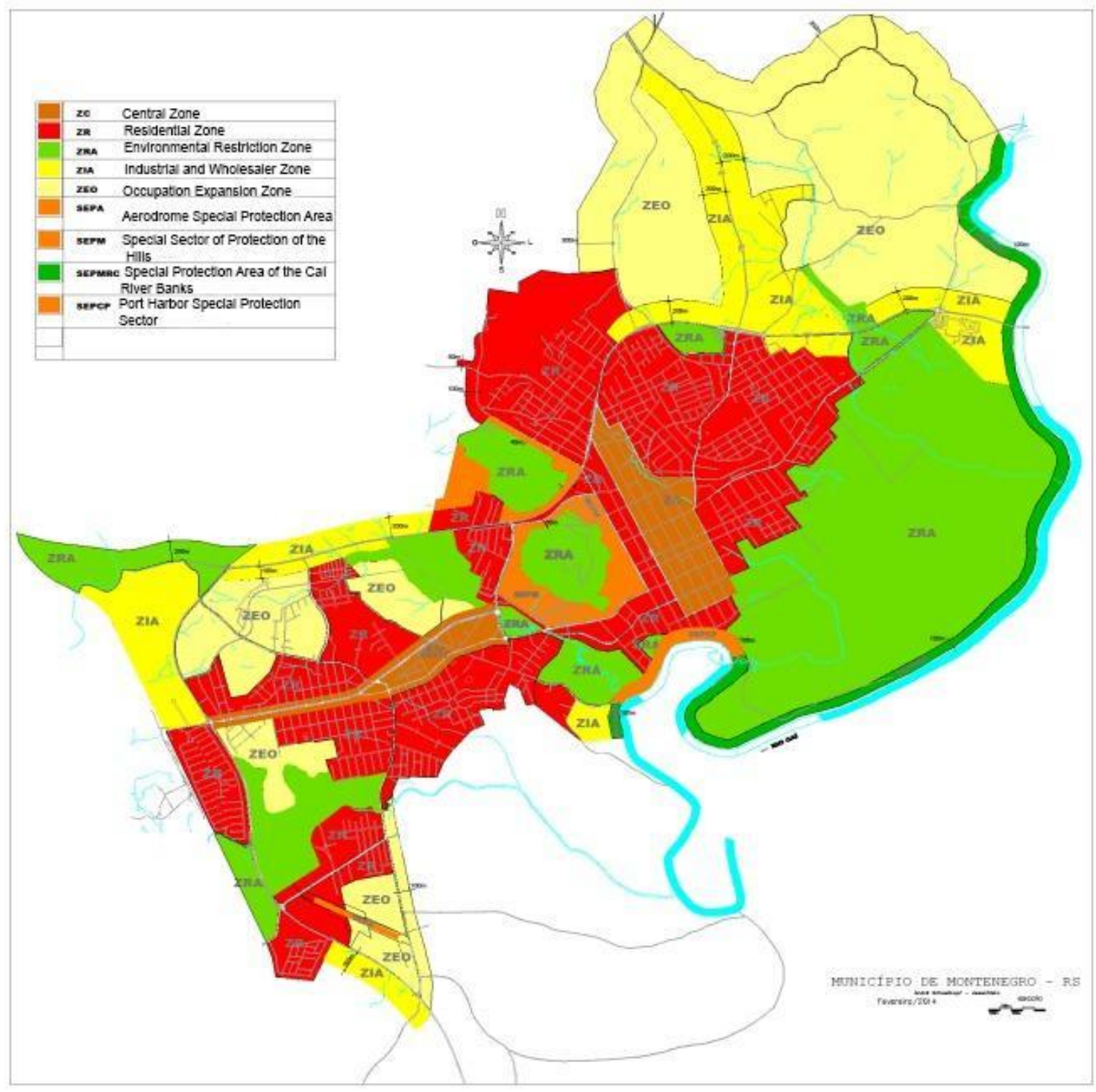

Picture 1 - Map of Montenegro/RS' municipality zones according to the 5.883 Act of January $13^{\text {th }}, 2014$.

All these documents were prepared by previous studies of the region and transformed into municipal laws to be observed by local public managers and by the population to guarantee the quality of life, economic progress and regional social order. It was observed that, in order to verify the effectiveness of such instruments in the control of urban expansion over the areas of environmental restriction, the present case study was carried out on the use and occupation of the permanent preservation areas in the Municipality of Montenegro/RS through a survey of the areas of permanent preservation on the Caí river banks - the most likely place for informal urban irregular expansion, in the vicinity of the urban perimeter of the municipality of Montenegro - RS, with the use of Unmanned Aerial Vehicle (UAV). 


\subsection{METHODOLOGY USED, AND RESULTS OBTAINED IN THE LIFTING OF THE USE AND OCCUPATION OF PERMANENT PRESERVATION AREAS IN THE ENVIRONMENTAL RESTRICTION AREA IN THE MUNICIPALITY OF MONTENEGRO/RIO GRANDE DO SUL}

Geotechnology allows us to analyze areas of different dimensions and for different purposes. The survey of areas such as the permanent preservation areas on the banks of the Cai river, near the urban perimeter of the municipality of Montenegro - RS through the use of remote sensors, such as satellites and Unmanned Aerial Vehicles (UAV), makes it possible to identify, quantify and periodically monitor changes in these locations.

The selected sample area - the Caí river banks - was strategically selected because, as a result of the vegetation, a broad and non-sloping soil, it is a region of environmental interest of the Municipality, including, in addition to the zone of environmental restriction, the Caí river banks special zone of protection and the port docks special zone of protection. These last two zones were inserted because they are continuous to the Environmental Restriction Zone and, as well as this one, also include areas of permanent preservation on the Caí river banks, these areas are of great importance for the health and conservation of the Municipality natural patrimony, and it should not be subject to occupation. It is considered that, in practice, due to their own characteristics, they are the most favorable places for an informal urban expansion by the low-income population, hence the natural resource margins, away from the urban centers and territories formally occupied by the real estate market and the dominant class of the Municipality, and that are generally more easily occupied when the state omission occurs on these territories less profitable from the economic point of view to the Municipality. 


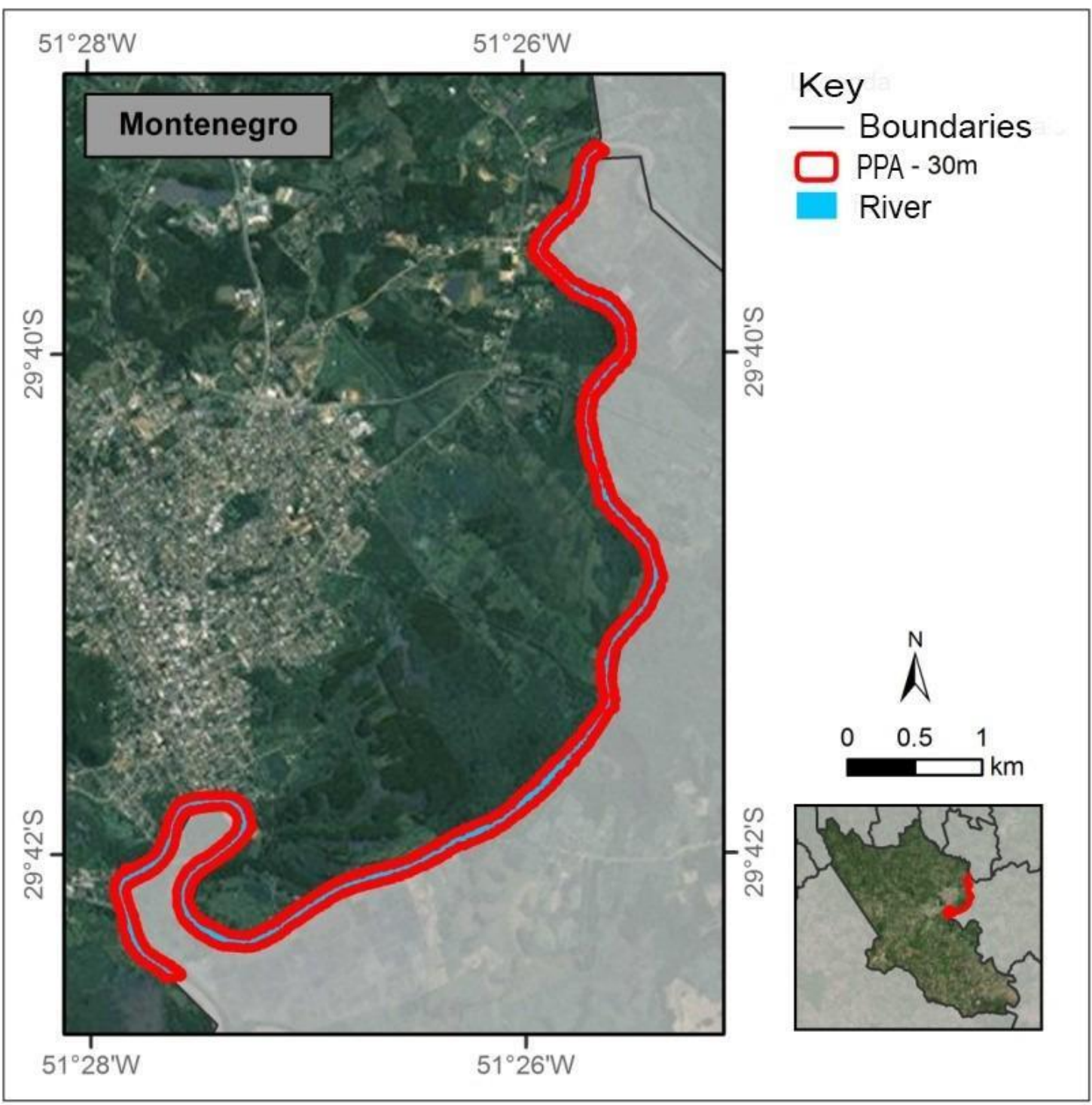

Image 2 - Overflown study area correspondent to the Caí river banks, with the purpose of identifying the conditions of the permanent preservation areas.

The survey of the selected area was carried out by technicians from the University of Caxias do Sul's Institute of Environmental Sanitation (ISAM) of the in October 2017. The activities carried out were described in the report of aerial survey activities in the Municipality of Montenegro/RS, where they describe:

The activities developed in this work refer to the aerial survey, by means of Unmanned Aerial Vehicle (UAV), near the urban perimeter of the municipality of Montenegro - RS. The overflown area corresponding to the Caí river banks, with the purpose of identifying the permanent preservation areas (APPs) conditions. Figure 1 shows the study area. 
The activities were carried out on October 31, 2017. On that date the team of the Institute of Environmental Sanitation went to the city to execute three scheduled flights for the study area.

The division into three flights for the worked area is justified by the increase of safety related to the autonomy of the flight equipment used, that is, the fixed wing UAV Maptor, Horus Aircrafts brand (Figure 2) ${ }^{48}$.

In the results obtained in the survey of the study area, we obtained images and flight records regarding the study area. Through continuous work, the georeferenced images were generated, which later were processed in the software Pix4d to create a mosaic that covers the entire study area.

From the mosaic obtained in the ArcMap10 software, the banks of the Caí river were identified and later the polygon was generated, defining the permanent preservation areas, for which the parameters of 30 meters are fixed from the edges of the watercourse, as indicated in Brazilian Forest Code $2012^{49}$.

The obtained maps have the fractional visual information obtained corresponding to the studied section, as shown below. The stretches in coloration are those areas where there was no image coverage at the point. However, it is found that such areas where this occurred are not part of the polygon of interest.

\footnotetext{
${ }^{48}$ Montenegro, Air Survey Report, ISAM - Instituto de Saneamento Ambiental (Caxias do Sul, 2017).

49 12.651 Act 2012.
} 

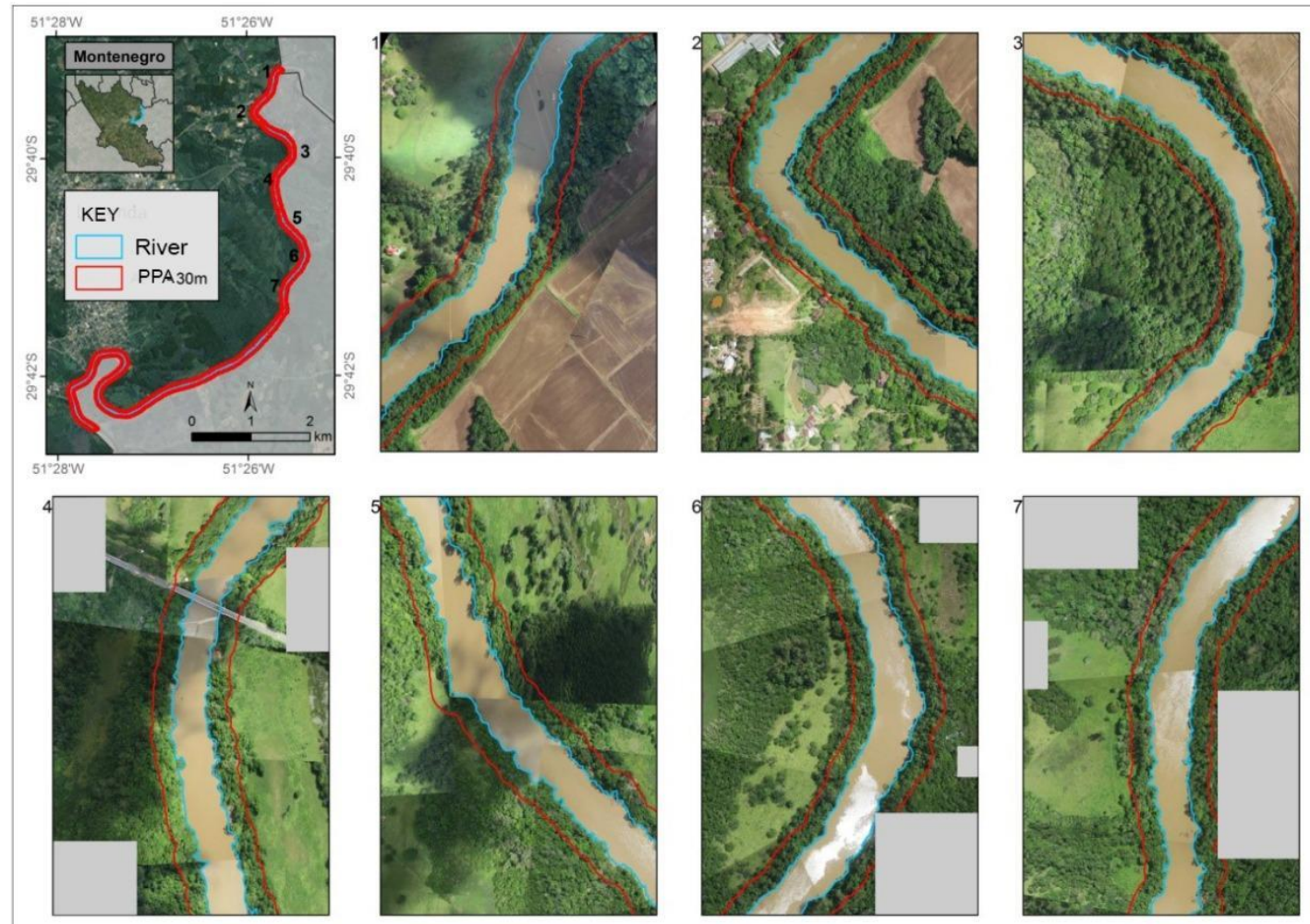

Image 3 - visual information corresponding to section 1 studied. Demonstrates the conditions of the Caí river bed - Montenegro/RS.
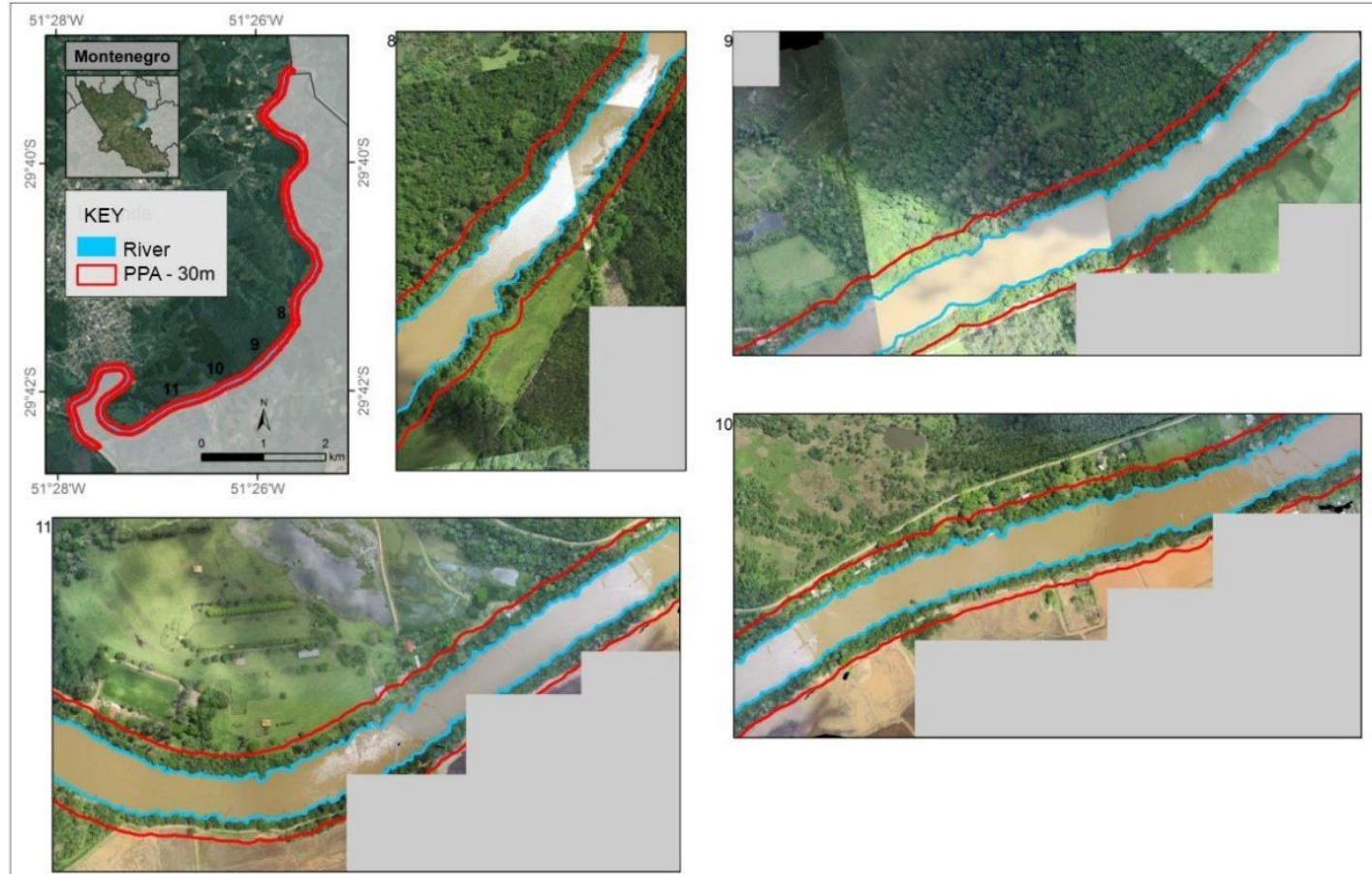
Image 4 - visual information corresponding to section 2 studied. Demonstrates the conditions of the Caí river bed - Montenegro/RS.

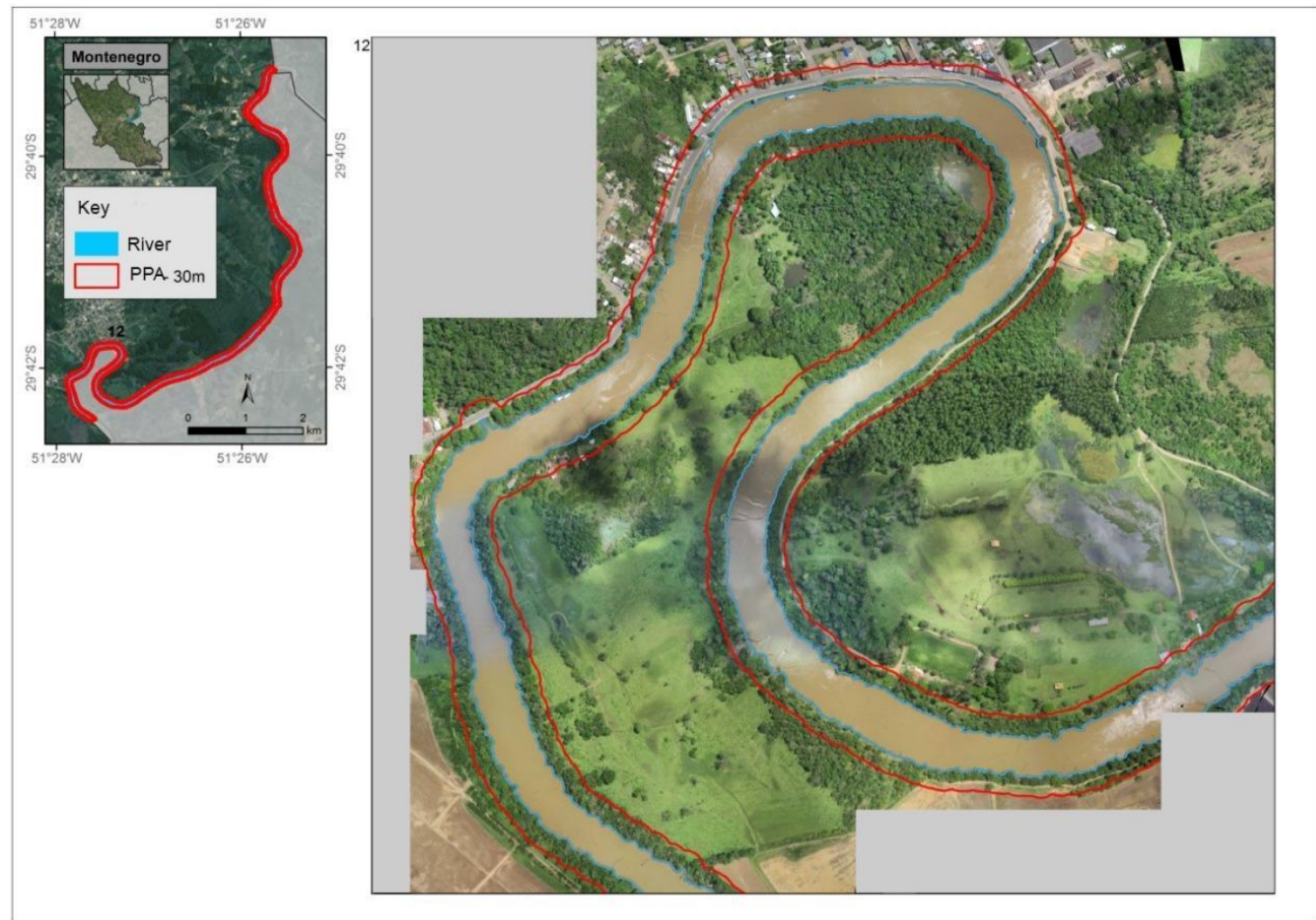

Image 5 - visual information corresponding to section 3 studied. Demonstrates the conditions of the Caí river bed - Montenegro/RS.

With such methods used, the results obtained were as follows:

Numerically, there are 38,30 hectares $\left(383,039,45 \mathrm{~m}^{2}\right)$ of permanent preservation areas on the Caí river bank corresponding to the municipality of Montenegro and inserted in the studied section.

The visual analysis of the results presents for sections 1 to 7 almost total absence of areas of anthropic use within the areas of permanent preservation. In section 2 it is possible to identify a small stretch of road and a building present in the PPAs, totaling about $535 \mathrm{~m}^{2}$, which corresponds to $0.14 \%$ of the permanent preservation areas studied. In addition, in section 4 , in the vicinity of the bridge there is an infrastructure work, which occupies $72 \mathrm{~m}^{2}$.

Section 9 has in its entirety only one building in the middle of natural cover, occupying $167 \mathrm{~m}^{2}$. Advancing to the next section (10), the number of anthropic interventions found increases in relation to previous sections, there are $940 \mathrm{~m}^{2}$ ( $0.25 \%$ of the PPAs studied) of buildings. A similar situation occurs in section 11 , where there are $474 \mathrm{~m}^{2}(0.12 \%$ of PPAs studied) of anthropic occupation.

The section named as 12 presents the greatest anthropic occupation in permanent preservation areas. Among roads, other infrastructure works, and buildings are $33.186 \mathrm{~m}^{2}$ (8.7\% of PPAs studied) of anthropic occupation in PPAs. 
In general, we highlight the presence of native forest in the permanent preservation areas, native vegetation in the region, common in areas adjacent to water courses, due to the high humidity that promotes the development of this type of vegetation. This, in turn, can also be called gallery forest, or ciliary forest, which constitutes a protective filter for the watercourses.

On this, the municipality of Montenegro presents in the studied section, a high conservation of the areas of permanent preservation. In addition, areas that do not comply with the legislation in relation to PPAs do not exceed $10 \%$ of the total area of study. There are 3.54 hectares between residences and infrastructure works found in the PPAs. This corresponds to $9.25 \%$ of the total area of areas classified as permanent preservation areas. ${ }^{50}$.

According to the data obtained, it is known that, in general, the native forest and vegetation originating in the region so important for the local balance, mainly because it corresponds to typical vegetation of watercourses with high humidity and rich in biological diversity characteristic of these locations is highly conserved.

The results indicate that the anthropic occupation of these sites is $9.25 \%$ of the total area classified as permanent preservation areas, which for a municipality with an intense population density and real estate growth, corresponds to a highly controlled index of human interference on preservation areas. It should be noted that $8.7 \%$ of the permanent preservation areas with anthropic occupation are not located in the zone of environmental restriction but are located in the special zone of protection of the banks of the Caí river and in the port pier special protection zone.

This indicates that from the $9.25 \%$ of Permanent Preservation Areas with anthropogenic influence, $8.5 \%$ are in section 12 which corresponds to a special zone of protection of the Caí river banks and in the port pier special protection zone. These two zones were inserted in the sample area because they have Permanent Preservation Areas of river banks, but they are not specifically subject to the same environmental restrictions of the environmental restriction zone. Therefore, although the municipality does not impose the same restrictions on these areas, these are special ecosystems with their own vegetation and, thus, are under legal guardianship and correspond to fragile and important territories for the maintenance of regional quality of life.

According to section 11 of the 5,883 supplementary Act 2014, which provides for the share of land in Montenegro, "it is established as anenvironmental restriction area- ERA corresponding to the areas necessary for the preservation of natural resources and for safeguarding the local and regional ecological balance ". The areas of permanent preservation of these areas should be legally protected, whereby, for these sites, the following objectives are established: preserving soil permeability,

\footnotetext{
${ }^{50}$ Montenegro, Air Survey Report, ISAM - Instituto de Saneamento Ambiental (Caxias do Sul, 2017).
} 
protecting and expanding the vegetation cover, discouraging soil occupation in order to guarantee the watersheds and minimizing flood damage, encourage the development of environmental leisure areas, support the development of programs aimed at environmental education, protection and restoration of natural environmental structures, stimulate the creation of private reserves of natural heritage and ensure the integrity of green areas, through their registration, precise delimitation and monitoring ${ }^{51}$.

What has remained evident with the results obtained with the present case study is that in the Municipality of Montenegro/RS the environmental legislation is generally observed, even when dealing with occupation along the waterways, that due to the ease of access to installation and housing, less need for engineering work, easier sewage disposal and waste disposal directly in the watercourse is where irregular occupations tend to occur due to informal urban expansions. Thus, environmental degradation at these sites is often related to unplanned changes in the use of these lands over and above the capacity of the soil to re-establish itself, which, because they are permanent preservation areas, have a more sensitive ecosystem.

Therefore, the analyzes carried out demonstrate the didactic and urbanistic effect of the Environmental Zoning within the Municipalities with a view to avoiding irregular urban expansion in relation to permanent preservation areas, and the importance of considering and using these instruments in local decision making by Municipal managers and other professionals involved, which is mandatory. Noting the impact of the legal instruments to preserve the areas of environmental restrictions in the Municipality of Montenegro/RS, their use constitutes of a practical and objective guideline that directs the form of occupation, creation of zones, sectors and kinds of use of land shares for development and activities for the healthy development of the Municipality of Montenegro/RS.

\subsection{USE AND OCCUPATION ANALYSIS OF ENVIRONMENTAL RESTRICTION AREAS IN THE MUNICIPALITY OF MONTENEGRO / RIO GRANDE DO SUL}

For all the above, in the case of Montenegro/RS, the boundaries established through the zones, consolidated in the Municipality zoning map, have a practical and didactic effect to the territory, which uses Public hearings and Public Policies to integrate and listen to the needs of citizens. Such attention is indispensable, since control is achieved as a result of the contentment of the local population with the socioeconomic guidelines adopted by the Municipality through the municipal management acts.

\footnotetext{
${ }^{51} 5.883$ complementary Act 2014, section 11, first paragraph, Montenegro's Town Hall 2014 (Brazil).
} 
According to the demographic census obtained through the Brazilian Institute of Geography and Statistics (IBGE) website, in 2010 the local population in Montenegro was 59.415 thousand inhabitants, and by the year 2016 the estimate was 63.551 thousand inhabitants ${ }^{52}$. Thus, the sense pointed out that the population increased to a significant level in a short time. Therefore, even though the zoning map is recent, made in the year 2014, its constant revision and inspection is indispensable, in order to contain the population's progress on the areas of environmental restriction, or more specifically in this case, on the river slopes, under penalty of not being met by the population the limits stipulated by the land use and occupation zones, and consequently the principles and objectives of the Municipal Master Plan, City Statute, Environmental Zoning and Federal Constitution of 1988.

Therefore, although in many municipalities the legal instruments available to the Public Power are presented formally correct, well elaborated and in accordance with the other laws in force, they do not denote efficacy, hence what will determine their compliance and control of the degradation on the areas of permanent preservation in the Municipality are the absorption by the population of the legal precepts and their adequacy to reality.

The more didactic, practical and assimilable by the population, the greater the effectiveness of the legal provisions provided by law. However, it is pointed out that the protection of the local natural heritage will only occur if the population considers the local territory as their own and is satisfied with the public administration and municipal management. In this sense, the municipality must grow with the population, encouraging socio-environmental education at different levels, and listening to the needs of the residents through public hearings.

It is pointed out that the municipality of Montenegro holds public hearings to open space for the local community to manifest itself, invest in local public policies, institute policies for the expropriation of risk areas and allocation of the low-income population, as well as keep updated the previous studies of urban expansion planning based on the reality and local cultural mutation, which highlights the importance of recognizing the fulfillment of local needs for the quality of life of the population and of the ecological heritage itself.

Even if the effects of global sustainability from the perspective of globalization do not seem to interfere, the truth is that the quality of life that directly affects the population depends very much on the initiative of the local communities through the affirmation of their citizenship, which is

52 Instituto Brasileiro de Geografia e Estatística (IBGE), Censo 2010, IBGE (Oct. 20 2017), http://www.censo2010.ibge.gov.br/sinopse/index.php?dados=9\&uf=00/. 
immediately expressed in local power more concretely ${ }^{53}$. Good local governance practices prioritize "trans-scale" ecology through the search for recovery and valuation of low-cost environmental protection alternatives for the reception of the place where citizens live, based on their sense of belonging to the soil and their local good relations.

In this way, this active action of the Municipal Public Power ensures the protection of the areas of environmental restriction of the Municipality, since the predominantly financial interests and the lack of seriousness and commitment of municipal management with the environment do not stand out. In the case of the Municipality of Montenegro, by introducing and comparing said parameters with Municipal legislation, the Municipality complies with the provisions of the Master Plan, since it provides in section 6 of the Master Plan "that said instrument is governed by the principles the social function of the city and of property, democratic management, environmental sustainability and the preservation of cultural heritage " 54 which actually happens.

In this same sense, the Master Plan still establishes that the social function of the city is guaranteed by the promotion of life quality, environmental sustainability, the use of redistributive income and land instruments, public control over land use and occupation, by democratic, participatory and decentralized management, by the integration of public/private actions and by the prioritization, in the elaboration and execution of programs, plans and projects, for groups of people who are in situations of risk and social vulnerability (section 8), which are examples of Public Policies applied in the local territory to ensure the sustainable development of the territory.

For the mentioned instrument, territorial and environmental development is related to the promotion of better occupation of the Municipal territory, with the following objectives: urban land use and orderly occupation - which allows the coexistence of diverse activities subordinated to environmental parameters and protection of the according to the law of land use and occupation, the provision of residential areas, the strengthening of district offices for decentralization in the provision of services to the rural environment, the protection of cultural and environmental assets (section 23), guidelines for land use and land use in the form of macro-zoning and urban zoning, to promote the occupation of urban voids in areas already endowed with infrastructure, and to promote the preservation, protection and recovery of the environment (section 24).

Having these objectives in mind, given the intense population growth and practical data obtained by the present case study, an adequate and effective Environmental Management in the

\footnotetext{
53 Ladislau Dowbor, Educação e Desenvolvimento Local (Sep. 2007), (Nov. 5, 2017) http://www.dowbor.org/artigos.asp.

${ }^{54} 4.759$ complementary Act 2007, section 6, Montenegro Town Hall.
} 
Municipality of Montenegro/RS, which prioritizes the quality of life of the population and values the social contribution for decision-making in public management. By establishing areas suitable for urban growth and other important Public Policies for the Municipality, these practices favor the occupation of urban areas in the indicated places and clearly observe the management and the way of conducting low-income people that are at the margins of the possibility of acquisition of goods in areas destined to this end, which ends up avoiding the informal occupation of environmental restriction areas, such as permanent preservation areas.

In municipalities where urban expansion occurs in these areas, the lack of access to a significant portion of the population, which does not find means or education for the purposes that are intended by law, is not considered in the preparation of plans. This part of the population is not introduced formally or informally in the areas destined to the urban expansion, inhabiting zones of risk and environmental preservation zones in the Municipalities by acquiescence and lack of inspection of the Public Power.

Thus, it is considered the effectiveness that the use of mitigation instruments of environmental impact has in the Municipality, the application of Public Policies in the local spaces for preservation, Environmental Education as a tool to protect the environment and especially the inclusion of the exercise of citizenship in public management decision-making means. It is noted that laws, especially environmental regulations, to be constitutional, are not enough to have been formally examined. They should be effective and materially in line with the higher basic values of the liberal and democratic fundamental order ${ }^{55}$, as well as with the value order of the Constitution, preserving correspondence with the elementary principles not written in the major letter, with the reality and possibility of its execution, presenting itself as an axiom of juridical stability and compliance with the principle of the social state ${ }^{56}$ (BONAVIDES 1997, 32). The balanced environment, indispensable to human development, is predisposed fundamentally by observing the interaction of man with nature and its ecosystems, considering that it is composed and, in this sense, with laws and Public Policies that have as specific and real purpose the protection and conservation of environmental protection areas.

It is in this context that the Municipal Public Administration must be active and count on the civil society in order to organize strategies of adequate growth of the Municipality. Local decisions must be taken together, so that the population does not present itself as a legal or executive imposition, but rather a consensus that comes to the conclusion that certain measures to be imposed

\footnotetext{
55 HANS KelSen, TeORIA PuRA do DiReito 65 (Martins Fontes 2006).

${ }^{56}$ PaUlo Bonavides, CuRso de Direito Constitucional 32 (7 ed., Malheiros 1997).
} 
through Municipal Public Policies bring improvements to all involved - read it, Public Power and inhabitants.

It is also considered the importance of environmental protection through the Municipality not only for all regulations that make this practice feasible, but for the recognition itself in the Brazilian federation brought by the Forest Code that delegates to the Municipalities the competence to define the limits of the marginal protection bands of watercourses - precisely because of their specific and local characteristics -, species of PPAs often associated with flooding caused by increased levels of rivers due to rainfall ${ }^{57}$, and the specific risks of occupying vulnerable areas - notably those that are at the mercy of landslides and floods that tend to intensify with climate change -, these hazards can be avoided by a Municipal Planning appropriate to reality, serious and precise - this effectiveness would not be obtained if it were not fulfilled by the nearest federated entity to the local community.

The protection of permanent preservation areas, when designing and implementing territorial planning in a municipality, should have as vectors the policies of the urban environment horizontal expansion, without removing or canceling existing restriction zones. In this sense, the Municipality of Montenegro/RS is an example to be followed, since it has dense, practical and specific municipal legislation, aligned with the specific purposes of the Master Plan and basic guidelines for urban growth, without compromising environmental patrimony, taking into account in view of the unavailability of environmental harmony for the healthy quality of life of the population, in compliance with the precepts contained in the 4,771/65 Act, section 2 and Article 30 of the Federal Constitution, 1988.

In the case under study, it is evident that the protection of the environment in the municipal normative instruments of the Municipality of Montenegro, especially of the permanent preservation areas in the banks of the Caí river, it is mainly considered in the proposals of development and local planning, demonstrating the effectiveness of the instruments of protection.

\section{CONCLUSION}

As it can be observed, the present essay sought to verify, from a specific case study, the limits and potentials of an effective local social empowerment capable of being reflected in cooperative actions between society and state - in casu, Municipality - in the field of environmental Protection. This is an effective corollary of the right to the city, given that local sustainability, supported by an active

\footnotetext{
${ }^{57} 12.651$ Act 2012, section 4, paragraph 9.
} 
citizenship and committed to environmental protection, is the maximum expression of the city as a living space based in an effective way on the dignity of the human person.

To do so, the analysis spectrum of this chapter has in fact focused on the reflexes of local normative production, considering that the law to be just, needs to be effective and legitimate first and foremost, adjusting to realities close to citizens. This perspective is maximized because the practical profile of the last decades shows that in the processes of urban planning - when they exist the Municipal Public Power is not linked to local aspects, which renders ineffective the application of municipal laws.

Therefore, the existence of legislative competence at the local level, especially in matters related to the specificities of urban planning and environmental protection, is not enough if such rules do not reflect a legislative process that is in fact committed to the cited requirements of legitimacy of the norm. This is because the process of constructing public decisions - be them administrative or legislative - must be in line with a broad process of interaction with local actors in society.

And it is this efficacy and legitimacy are questioned in the scope of this case study, from the 5.883 complementary Act 2014 that establishes the specific parameters and directives of zoning, use and occupation of the soil in the Municipality of Montenegro/Rio Grande do Sul, based on previous studies of local socio-environmental viability. The data presented and its comparison with the theoretical assumptions as well as with the Brazilian legal systematization showed that the legislation under debate, because it is consistent with the specific reality of the Municipality, is essential for the conservation of the local natural heritage, hence the limits imposed to the urban expansion and protection of environmental restriction zones are generally observed by the population.

It is worth mentioning that the use of Public Policies in local spaces and, in particular, the implementation of formal and non-formal Environmental Education at all levels of education are a means of including civil society in local decisions and make citizens members active in controlling and supervising the preservation of the environmental restriction zones within the Municipalities, these measures representing strategic forms of socio-environmental control. It is these strategies that confer legitimacy either in the formation process or in the follow-up of the effective process of local law enforcement, which in turn manifests the real sense of the general principles guided by the Constitutional Charter.

Environmental Education, therefore, should be directed towards active citizenship by showing the sense of belonging and co-responsibility of these with nature, which through collective and organized action seeks to understand and overcome the structural and conjunctural causes of 
environmental problems within urban spaces. The epistemological strategies of environmental complexity, the ethics of a dialogue of knowledge and the pedagogy of an Environmental Education are thus fundamental principles of this strategy of sustainable development and the construction of an environmental rationality.

The Municipality, in turn, represents the locus where the jobs, the goods, the municipal government headquarters, the public squares, the cultural options, the restaurants and the main places of leisure and other public services (schools, hospitals, registry offices). Thus, the right to a sustainable territory is a concept under construction, whose constitutional dimension stems from the Democratic Socio-environmental State of Law, from the provisions of sections 182 and 183, in addition to that contained in section 6 - right to democratic management and housing - all from the Brazilian Federal Constitution. These are guaranteed benefits by the fundamental rights contained in the Magna Carta - which completes its 30 years in Brazil, being the Municipality the ideal space for its realization, primarily.

The population, which is already mostly installed in the Municipalities, should increasingly have access to a decent life through the implementation of Public Policies in local spaces, in a balanced environment, to be ensured through the Master Plan by the implementation of urban planning. This is to ensure decent living conditions for all citizens, seeking a sustainable development from these geological spaces. With the use of such tools, the aim is to democratize the priority choices of each part of civil society, as well as the democratic participation of the entire population in the process of sustainable management within the Municipal urban environment.

In the process of sustainable development with a view to minimizing socioeconomic impacts in different regions with characteristics peculiar to each of them, the use of environmental zoning becomes essential to mitigate such advances in areas of special interest to the population. The implementation of environmental zoning is not a discretionary exercise of the Public Power motivated by the convenience and opportunity in its establishment. It is a power linked to environmental protection it is a duty of civil society and the Public Power.

In this perspective of sustainable development in compliance with the precepts of environmental zoning, it is not a question of opposing economic and urban development. On the contrary, it aims at the support of the cultural and ecosystemic organization, in which an ecologically sustainable, economically sustainable and, socially equitable and fair process of development is rooted. 
The Brazilian Legal System in force has at its most diverse levels of action several instruments that impose on the Government measures that aim at Integrated Environmental Management with the scope of protecting the national natural heritage. Specific measures are delegated to municipalities as the entity that is closest to the local reality and elaborated with the scope of primarily ensuring regional and proper sustainable development to mitigate environmental impacts on areas of municipal environmental interest before even considering possibilities of economic growth of the local entity.

Like the present case study, good practices of environmental protection and recognition of the role of citizens should be shared, while it is well known that local action is a measure of confirmation of the meaning of citizens' belonging to their space. This is the maximum expression of the principle of subsidiarity, which in Brazil is an implicit rule, resulting from criteria of decentralization and democracy.

Therefore, the clear analysis of the effects of local rules is emphasized - what was sought in this study, including concrete verification of its effects. This is because it is in the local sphere that the instruments of social control are strengthened to restrain the harmful effects of a refractory globalization - often - of the guarantees provided in the constitutions, those of limitation to the national space.

The feeling of belonging to the place is one of the basic factors that generate the protection of the environment and the urban environment in which the population is inserted. The more the person feels belonging to the place, the more he preserves and maintains the public patrimony, whether natural or not, which highlights the importance of popular participation in decisions and municipal choices. The social functions of the city and property will only be achieved if they are consistent with the other objectives and premises of Brazilian federalism, as well as the feeling of love, zeal and care with what belongs to them.

\section{REFERENCES}

AGUIAR, Roberto Armando Ramos de. Direito do meio ambiente e participação popular. Brasília: Edições Ibama, 1998.

ANTUNES, Paulo de Bessa. Direito ambiental. 16. ed. São Paulo: Atlas, 2014.

BANUNAS, loberto Tatsch. Poder de polícia ambiental e o município: guia jurídico do gestor municipal ambiental orientador legal do cidadão ambiental. Porto Alegre: Saluna, 2003.

BARDET, Gaston. O urbanismo. Campinas, Papirus, 1990. 
BONAVIDES, Paulo. Curso de direito constitucional. 7. ed. São Paulo: Malheiros, 1997.

BRASIL. (Constituição, 1988). Constituição da República Federativa do Brasil. Brasília, 1988.

Disponível em: <http://www.planalto.gov.br/ccivil_03/constituicao/constituicao.htm>. Acesso em: 2017.

BRASIL. Decreto no 4.297 de 10 de julho de 2002. Regulamenta o art. 9o, inciso II, da Lei no 6.938, de 31 de agosto de 1981, estabelecendo critérios para o Zoneamento Ecológico-Econômico do Brasil ZEE, e dá outras providências. Brasília. Disponível em: <http://www.planalto.gov.br/ccivil_03/decreto/2002/d4297.htm>. Acesso em: 2017.

BRASIL. Lei 12.651/2012. Dispõe sobre a proteção da vegetação nativa; altera as Leis $n^{\circ} 6.938$, de 31 de agosto de 1981, 9.393, de 19 de dezembro de 1996, e 11.428, de 22 de dezembro de 2006; revoga as Leis $\mathrm{n}^{\text {os }} 4.771$, de 15 de setembro de 1965, e 7.754, de 14 de abril de 1989, e a Medida Provisória $n^{\circ}$ 2.166-67, de 24 de agosto de 2001; e dá outras providência. Disponível em:

<http://www.planalto.gov.br/ccivil_03/_ato2011-2014/2012/lei/l12651.htm>. Acesso em: 2017.

BRASIL. Lei no 10.257 de 10 de julho de 2001. Regulamenta os arts. 182 e 183 da Constituição Federal, estabelece diretrizes gerais da política urbana e dá outras providências. Disponível em: <http://www.planalto.gov.br/ccivil_03/leis/LEIS_2001/L10257.htm>. Acesso em 2017.

BRASIL. Lei no 6.938 de 31 de agosto de 1981. Dispõe sobre a Política Nacional do Meio Ambiente, seus fins e mecanismos de formulação e aplicação, e dá outras providências. Disponível em: <http://www.planalto.gov.br/ccivil_03/leis/L6938.htm>. Acesso em: 2017.

BRASIL. Lei no 12.651: Código Florestal Brasileiro. 2012. Disponível em: <http://www.planaIto.gov.br/ccivil_03/_Ato2011 2014/2012/Lei/L12651compilado.htm>. Acesso em: 27 nov. 2013.

BRASIL. Presidência da República. Secretaria de Assuntos Estratégicos. Programa de Zoneamento Ecológico-Econômico da Amazônia legal. Brasília, DF: SAE/PR/CCZEE, 1991.

CIDADES sustentáveis, subsídios à elaboração da Agenda 21 brasileira. Brasília, Ministério do Meio Ambiente, 2000.

COSTA, Marli Marlene da Costa; REIS Suzéte da silva Reis. Espaço local: o espaço do cidadão e da cidadania.In: HERMANY, Ricardo (Org.). Gestão local e políticas públicas. Santa Cruz do Sul: Editora IPR, 2010.

DIAS, Daniella S. A efetividade do direito urbanístico após vinte anos da promulgação da Constituição brasileira. Revista de Informação Legislativa, Brasília, v. 47, n. 186, abr./jun. 2010.

DOWBOR, Ladislau. Educação e Desenvolvimento Local. Set. 2007. Disponível em: <http://www.dowbor.org/artigos.asp>. Acesso em: 05 nov. 2017. FIORILLO, Celso Antônio Pacheco. Curso de direito ambiental brasileiro. 8 ed. São Paulo: Saraiva, 2007.

GIACOBBO, G. E.; HERMANY, R. Descentralização e Municipalismo no Brasil. In: António Cândido de Oliveira; Ricardo Hermany;. (Org.). Municipalismo: Perspectivas da descentralização na América Latina, na Europa e no Mundo. 1ed. Brasília: Confederação Nacional de Municípios, 2017, v. 1, p. 36 75. 
HESSE, Konrad. A força normativa da constituição. Tradução Gilmar Ferreira Mendes. Porto Alegre: Fabris, 1991.

HESSE, Konrad. Elementos de direito constitucional da República Federal da Alemanha. Tradução de Luis Afonso Heck. Porto Alegre: Fabris, 1998.

INSTITUTO BRASILEIRO DE GEOGRAFIA E ESTATÍSTICA. Censo 2010. Disponível em:<http://www.censo2010.ibge.gov.br/sinopse/index.php?dados=9\&uf=00/>. Acesso em: 20 out. 2017.

INSTITUTO BRASILEIRO DE GEOGRAFIA E ESTATÍSTICA. Cidades. Disponível em: <http://www.cidades.ibge.gov.br>. Acesso em: 20 out. 2017.

INSTITUTO BRASILEIRO DE GEOGRAFIA E ESTATÍSTICA. Definição de Município de médio porte: de 10 mil à 50 mil habitantes. Disponível em:

$<$ http://censo2010.ibge.gov.br/noticias?view=noticia\&id=1\&idnoticia=2019\&busca=1\&t=indicadores -sociais-municipais-2010-incidencia-pobreza-maiormunicipios-porte-medio >. Acesso em: 05 nov.2017.

INSTITUTO BRASILEIRO DE GEOGRAFIA E ESTATÍSTICA. Instrumentos de planejamento urbano. Disponível em: <http://www.mma.gov.br/cidades-sustentaveis /planejamento-ambientalurbano/instrumentos-de-planejamento>. Acesso em: 05 out. 2017.

JARDIM, Zélia Leocádia da Trindade. Regulamentação da política urbana e garantia do direito à cidade. In: COUTINHO, Ronaldo; BONIZZATO, Luigi (Coord.). Direito da cidade: novas concepções sobre as relações jurídicas no espaço social urbano. Rio de Janeiro: Lumen Juris, 2007.

KELSEN, HANS. Teoria pura do direito. São Paulo: Martins Fontes, 2006.

LEFF, Enrique. A complexidade ambiental. São Paulo: Cortez, 2003.

LEFF, Enrique. Ecologia, capital e cultura: a territorialização da racionalidade ambiental. Petrópolis: Vozes, 2009a.

MACHADO, Paulo Affonso Leme. Direito ambiental brasileiro. 12. ed. São Paulo: Malheiros, 2004.

MARIN, Jeferson Dytz; LUNELLI, Carlos Alberto. Processo Ambiental, Efetividade e as Tutelas de Urgência. Veredas do Direito: v. 7, n. 13/14, ago. 2011. Disponível em:

<http://www.domhelder.edu.br/revista/index.php/veredas/article/view/17>. Acesso em: 2018.

MEIRELLES, Hely Lopes. Direito municipal brasileiro. 13. ed. atualizada por Célia Marisa Prendes e Márcio Schneider Reis. São Paulo: Malheiros, 2003.

MONTENEGRO. Câmara Municipal. Lei complementar no 4.759/2007. Reestrutura o Plano Diretor de Desenvolvimento do Município de Montenegro e da outras providencias. Disponível em:

<https://www.montenegro.rs.leg.br/leis/plano-diretor/LC\%204759.pdf/view>. Acesso em 2017.

MONTENEGRO. Câmara Municipal. Lei complementar no 5.883/2014. 2014d. Dispõe sobre zoneamento, uso e ocupação do solo do Município De Montenegro e da outras providencias. 
Disponível em: <https://www.montenegro.rs.leg.br/leis/planodiretor/lei\%20zoneamento.pdf/view>. Acesso em: 2017.

MOTTA, Suetônio. Urbanização e meio ambiente. Rio de Janeiro: Abes, 2003.

MUMFORD, Lewis. A cidade na história. Tradução de Neil da Silva. 4. ed. São Paulo: M. Fontes, 1998.

OLIVEIRA, Isabel Cristina Eiras de. Estatuto da Cidade: para compreender... Rio de Janeiro: IBAM\DUMA, 2001.

PRESTES, Vanêsca Buzelato. Dimensão constitucional do direito à cidade e formas de densificação no Brasil. Dissertação (Mestrado em Direito) - Faculdade de Direito, Pontifícia Universidade Católica do Rio Grande do Sul. Porto Alegre, 2008.

RECH, Adir Ubaldo; RECH, Adivandro. Direito urbanístico. Caxias do Sul: EDUCS, 2015.

$\mathrm{RECH}$, Adir Ubaldo; RECH, Adivandro. Direito urbanístico: fundamentos para construção de um Plano Diretor sustentável na área urbana e rural. Caxias do Sul: Educs, 2010.

RECH, Adir Ubaldo; RECH, Adivandro. Zoneamento ambiental como plataforma de planejamento da sustentabilidade: instrumentos de uma Gestão Ambiental, urbanística e agrária para o desenvolvimento sustentável. Caxias do Sul: Educs, 2012.

RELATÓRIO DE ATIVIDADES MONTENEGRO / LEVANTAMENTO AÉREO. ISAM - Instituto de saneamento ambiental. Caxias do Sul, 2017.

SANTIN, Janaína Rigo; MATTIA, Ricardo Quinto. Direito Urbanístico e Estatutos das Cidades. Revista de Direito Imobiliário, São Paulo, v. 30, n. 63. 2007.

SANTOS, Milton. Por uma nova globalização: do pensamento único a consciência universal. 22. ed. Rio de Janeiro: Record, 2012.

SÉGUIN, Elida. Estatuto da Cidade. Rio de Janeiro: Forense, 2002b.

SILVA, José Afonso. Direito ambiental brasileiro. 4. ed. São Paulo: Malheiro, 2006a.

SILVA, José Afonso. Direito ambiental brasileiro. Direito urbanístico brasileiro. 3. ed. rev. atual. São Paulo: Malheiros, 1997.

SILVA, José Afonso. Direito ambiental constitucional. 4. ed. São Paulo: Malheiros, 2002.

SILVA, José Afonso. Direito urbanístico brasileiro. São Paulo: Revista dos Tribunais, 1981.

SORRENTINO, Marcos et al. Educação Ambiental como política pública. Educação e Pesquisa, São Paulo, v. 31, n. 2, 2005.

Trabalho recebido em 23 de julho de 2019

Aceito em 15 de março de 2021 